
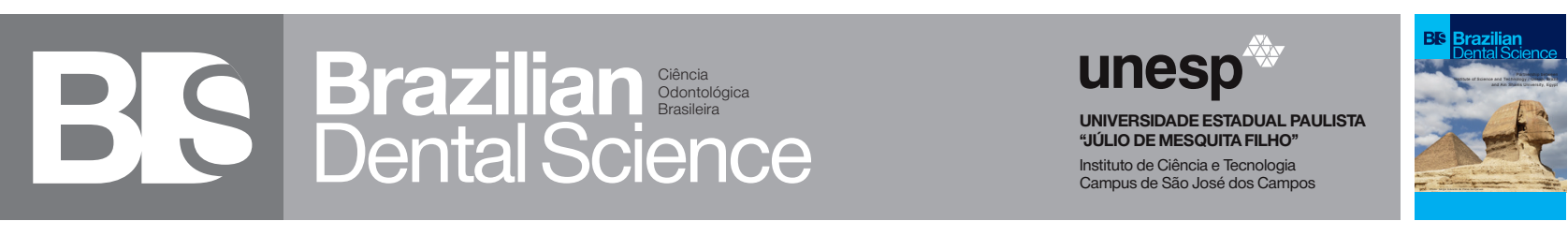

\title{
Synthesis and morphological characterization of Polycaprolactone (PCL) membranes with tara extract (Caesalpinia spinosa)
}

Síntese e caracterização morfológica de membranas eletrofiadas de Policaprolactona (PCL) com extrato de tara (Caesalpinia spinosa)

Jhenifer Rodrigues SILVA ${ }^{1}$, Tabata Prado SATO ${ }^{2}$, Alexandre Luiz Souto BORGES ${ }^{2}$

1 - São Paulo State University (Unesp) - Institute of Science and Technology - São José dos Campos - SP - Brazil.

2 - São Paulo State University (Unesp) - Institute of Science and Technology - São José dos Campos - Department of Dental Materials and Prosthodontics - SP - Brazil.

\section{ABSTRACT}

Objective: This study aimed the synthesis and morphological characterization of PCL electrospun fibers containing tara extract. Material and Methods: For this, tara extract synthesis was performed by two different extraction methods: rotary evaporator and extractor soxhlet. Then, two solutions were prepared by dissolving $3 \mathrm{~g}$ of PCL in $2 \mathrm{~mL}$ of Acetone. The first solution used $0.4 \mathrm{~mL}$ tara extract obtained by RE and the second solution used $0.4 \mathrm{~mL}$ tara extract obtained by SE. After the solutions electrospinning, under different parameters, obtaining It was obtained the experimental groups: ChTa 1 nanofibers with RE extract, under $12 \mathrm{Kv}$; ChTa 2 nanofibers with RE extract, under $15 \mathrm{Kv}$; ChTa 3 nanofibers with ES extract, under $12 \mathrm{Kv}$ and ChTa 4 nanofibers with ES extract, under $15 \mathrm{kV}$. Scanning electron micrographs were performed for morphological analysis. Results: Fiber formation was observed for all parameters. About the fiber diameter: ChTa 1 presented a mean of $0.82 \pm 0.36 \mu \mathrm{m}$, ChTa $21.232 \pm 0471 \mu \mathrm{m}$, ChTa $31.469 \pm 0.614 \mu \mathrm{m}$ and ChTa $41.017 \pm 0.417$. Also the beads formation was analyzed: ChTa 1 group presented 8 beads, ChTa 2 presented 5, ChTa 3 presented 30 and ChTa 4 presented 15 beads. Conclusion: It can be concluded that it is possible to obtain an effective synthesis of electrospun membranes of PCL and Caesalpinia spinosa extract, indicating a potential of therapeutic application for lesions such as prosthetic stomatitis.

\section{KEYWORDS}

Candidiasis; Nanofibers; Tannins.

\section{RESUMO}

Objetivo: Este estudo objetivou a síntese e a caracterização morfológica de fibras eletrofiadas de PCL contendo extrato de tara, caracterizando sua morfologia. Material e Métodos: Para isso, a síntese do extrato de Tara foi realizada por dois diferentes métodos de extração: Evaporador rotativo e Extrator de soxhlet. Em seguida, duas soluções foram preparadas dissolvendo $3 \mathrm{~g}$ de PCL em $2 \mathrm{~mL}$ de acetona. A primeira solução utilizou $0,4 \mathrm{~mL}$ de extrato de Tara obtida por ER. A segunda solução utilizou $0,4 \mathrm{~mL}$ de extrato de Tara obtida por ES. Após as soluções serem eletrofiadas, sob diferentes parâmetros, obtiveram-se os grupos experimentais: ChTa 1 nanofibras com extrato de RE, sob 12Kv; ChTa 2 nanofibras com extrato de RE, sob $15 \mathrm{Kv}$; ChTa 3 nanofibras com extrato de ES, com menos de $12 \mathrm{Kv}$ e nanofibras de ChTa 4 com extrato de ES, sob $15 \mathrm{kV}$. Micrografias eletrônicas de varredura foram realizadas para análise morfológica. Resultados: A formação de fibras foi observada para todos os parâmetros. Quanto ao diâmetro da fibra: ChTa 1 apresentou uma média de $0,82 \pm 0,36 \mu \mathrm{m}$, o ChTa $21,232 \pm 0471 \mu \mathrm{m}$, o ChTa $31,469 \pm 0,614 \mu \mathrm{m}$ e o ChTa $41,017 \pm 0,417$. Também foi analisada a formação dos beads: o grupo ChTa 1 apresentou 8 beads, o ChTa 2 5, o ChTa 330 e o ChTa 4 15. Conclusão: Pôde-se concluir que é possível obter uma síntese efetiva de membranas eletrofiadas de extrato de PCL e Caesalpinia spinosa, indicando um potencial de aplicação terapêutica para lesões como a estomatite protética.

\section{PALAVRAS-CHAVE}

Candidiases; Nanofibras; Taninos. 


\section{INTRODUCTION}

$\mathrm{T}$ he prosthetic stomatitis, identified as an erythematous lesion on the palate and alveolar ridge, has a multifactorial origin from processes such as trauma, microbial biofilm, the use of maladaptive prostheses, xerostomia and Candida albicans infection $[1,2]$.

Complete Denture wearers typically present this pathology [3] and for their treatment there are standard antifungal mechanisms such as Nystatin, Miconazole and Ketoconazole [2,4] and also complementary therapies like the use of propolis [5], herbal therapies $[2,6]$ and photodynamic therapy $[7,8]$.

In this sense, the search for bioactive compounds present in plant extracts, herbal medicines, is currently growing to be used in the areas of medicine and dentistry.

Thus, recent studies progress in the use of active principles of plants such as Tara (Caelsapina spinosa), already used in the leather and food industry, for example, treatment of oral lesions $[9,10]$.

The genus Caelsapina has more than 150 species in tropical and subtropical areas in the world [11]. Caelsapina spinosa, known as Tara, is a legume native to Peru [12], used frequently in other Andean countries, such as Bolivia, Colombia, and Ecuador in medicine since pre-Hispanic times.

Tara has a high concentration of Tannins, (between 40\% and 60\%), as main constituents, which are phenolic compounds with astringent properties, antiviral, antibacterial, antiparasitic, antioxidant [13], antitumor [14,15] and anticancer [16].

Within this range of studies regarding medicinal therapies is the synthesis of biomaterials in the form of nanofibers, structures that can be obtained by means of the technique of electrospinning [17].
In electrospinning, a polymer solution is placed in a system, that basically consists of a high voltage source, metal capillary, a syringe and a collector, is used to produce nanofibers, which is dispersed almost randomly by the air [18].

The application of a high voltage on a syringe containing a polymer solution, succeeded by an ejection of a direct jet in a collector, after solvent evaporation produces solid fibers [19] and this technique is present in the different areas such as biotechnology, guided tissue regeneration and drug delivery [20].

For this, electrospun nanofibers have become promising biomaterials because of their fibrous structure, their considerable contact area and their flexibility [21].

Polymers such as polycaprolactone (PCL) are defined as a synthetic, semicrystalline, hydrophobic, biocompatible and highly permeable polymer [22] that has as its property a slow degradation [23] and great utility in the medical area for sutures and controlled delivery of drugs [24].

PCL is a linear aliphatic polyester with a semicrystalline character. It is one of the most researched synthetic polymers in the world and the FDA-Food and Drug Administration approved it for medical applications in the United States of America [18]. The degradation of PCL is slow, due to its crystallinity and hydrophobic characteristic, and therefore it is indicated for long-term implants [25].

The incorporation of Tannins to the polymer nanofibers allows the availability of the herbal medicine and delivery control, improving the therapeutic efficacy and reducing the toxicity [26].

Thus the aim of this study was to synthesize nanofibers containing Caesalpinia spinosa extract to be applied as a preventive stomatitis therapy in complete dentures. 


\section{MATERIAL AND METHODS}

\section{EXTRACTION OF TARA BY ROTARY EVAPORATOR (RE)}

All procedures in this process can be seen in figure 1 , which $10 \mathrm{~g}$ of Tara leaf was immersed in $100 \mathrm{~mL}$ of PA chloroform and the product was placed at Steam Route until total evaporation of the solvent for $3 \mathrm{~h}$.

Then, process product was filtered using filter paper and anhydrous sodium sulfate was used to remove the water. Sample was placed in water bath and after that, in a dissector, resulting in $2.9 \%$ of extract of the Tara leaf.

\section{EXTRACTION OF TARA BY EXTRACTOR SOXHLET (ES)}

All procedures in this process can be seen in figure 2, which $10 \mathrm{~g}$ of Tara leaf was immersed in $300 \mathrm{~mL}$ of PA chloroform and then placed in Soxhlet Extractor for 12 hours.

And just as in the previous process, the product was filtered and placed in a dissector, resulting in $17,5 \%$ of extract of the Tara.

\section{CALCULATION OF PHYTOTERAPIC EXTRACT PERFORMANCE}

For this study, Caelsapina spinosa the yield was calculated based on the dry material method that is standardized and can be repeated any time, without significant deviations [28].

\section{QUANTIFICATION OF TANINS}

The remaining extract was used to spectrophotometer analysis. By this spectrophotometer procedure the mass spectral plot of the extract was obtained.

\section{POLYMERIC SOLUTION}

Two solutions were prepared by dissolving $3 \mathrm{~g}$ of PCL in $2 \mathrm{~mL}$ of Acetone. The first solution used $0.4 \mathrm{~mL}$ tara extract obtained by $\mathrm{RE}$ and the second solution used $0.4 \mathrm{~mL}$ tara extract obtained by SE. Both solutions were maintained under constant stirring (300rpm) at room temperature (25 OC) for $12 \mathrm{~h}$.

\section{ELECTROSPINNING}

The electrospinning equipment consists of a high voltage source, a plastic syringe and a collector. Nanofiber membranes were obtained under different voltages (12 and $15 \mathrm{kV}$ ) and distances, from metallic capillary to the collector, and a constant flow rate of $0.8 \mathrm{mLh}-1$.

It was obtained four groups (Table 1): ChTa 1 nanofibers with RE extract, under $12 \mathrm{Kv}$; ChTa 2 nanofibers with RE extract, under $15 \mathrm{Kv}$; ChTa 3 nanofibers with ES extract, under $12 \mathrm{Kv}$ and ChTa 4 nanofibers with ES extract, under $15 \mathrm{kV}$.

\section{CHARACTERIZATION OF NANOFIBERS}

\section{Scanning Electron Microscopy (SEM)}

Scanning electron micrographs were performed to verify the quality of the fiber generated and beads presence.

Specimens were cut into squares $(0.4 \mathrm{x}$ $0.4 \mathrm{~cm}$ ), fixed on a support and coated with a thin layer of gold under low atmospheric pressure (SC7620 'Mini' Sputter Coater / Glow Discharge System, Emitech, East Sussex, UK).

Micrographs were performed (Inspect S 50, FEI Company, Brno, Czech Republic) operating under high vacuum, $15-25 \mathrm{kV}$, and spot 5.0. 


\section{Analysis of fiber diameter and presence of beads}

The micrographs obtained were analyzed in Image J image software, from which it was possible to measure the fibers mean diameter and the presence of beads.

For this, the micrographs were divided into 16 frames. In each frame, beads were counted as well as the fiber diameters.

\section{Statistical analysis}

The collected data were submitted to Analysis of Variance ANOVA 1-factor, followed by Tukey test $(\mathrm{P}<0.05)$.

\section{RESULTS}

The descriptive analysis of the synthesized material was carried out from the scanning electron micrographs obtained from the specimens with the addition of extract synthesized under smaller (Figure 3) and higher yield (Figure 4).

Fiber formation was observed under 12 and $15 \mathrm{kV}$ and $12 \mathrm{~cm}$ the distance of the metallic capillary to the collector of, with little significant discontinuity formation in the fibers.

Under Image $\mathrm{J}$ analysis, a mean fiber diameter of each group was obtained: ChTa 1 presented a mean of $0.82 \pm 0.36 \mu \mathrm{m}$, ChTa $21.232 \pm 0471 \mu \mathrm{m}$, ChTa $31.469 \pm$ $0.614 \mu \mathrm{m}$ and ChTa $41.017 \pm 0.417$ (Figure 5).

Also the beads formation was analyzed: ChTa 1 group presented 8 beads, ChTa 2 presented 5, ChTa 3 presented 30 and ChTa 4 presented 15 beads (Figure 6).
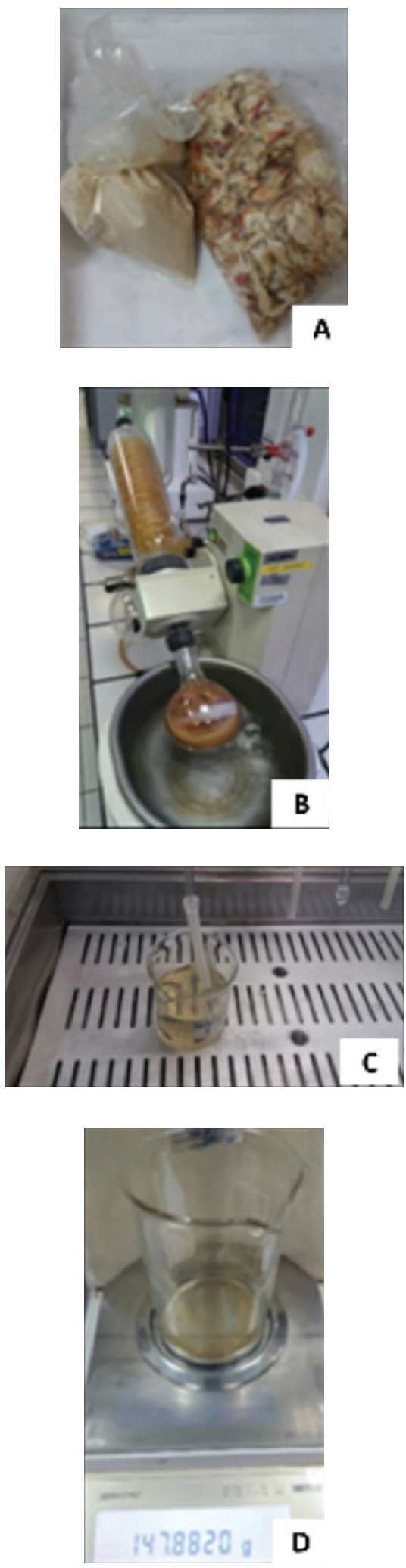

Figure 1 - Phytotherapeutic extraction process (Rotary evaporator): a) Shredded Tara leaves, b) Rota-Vapor, c) water bath with $\mathrm{O}_{2}$, d) Extraction transferred to Bécker. 

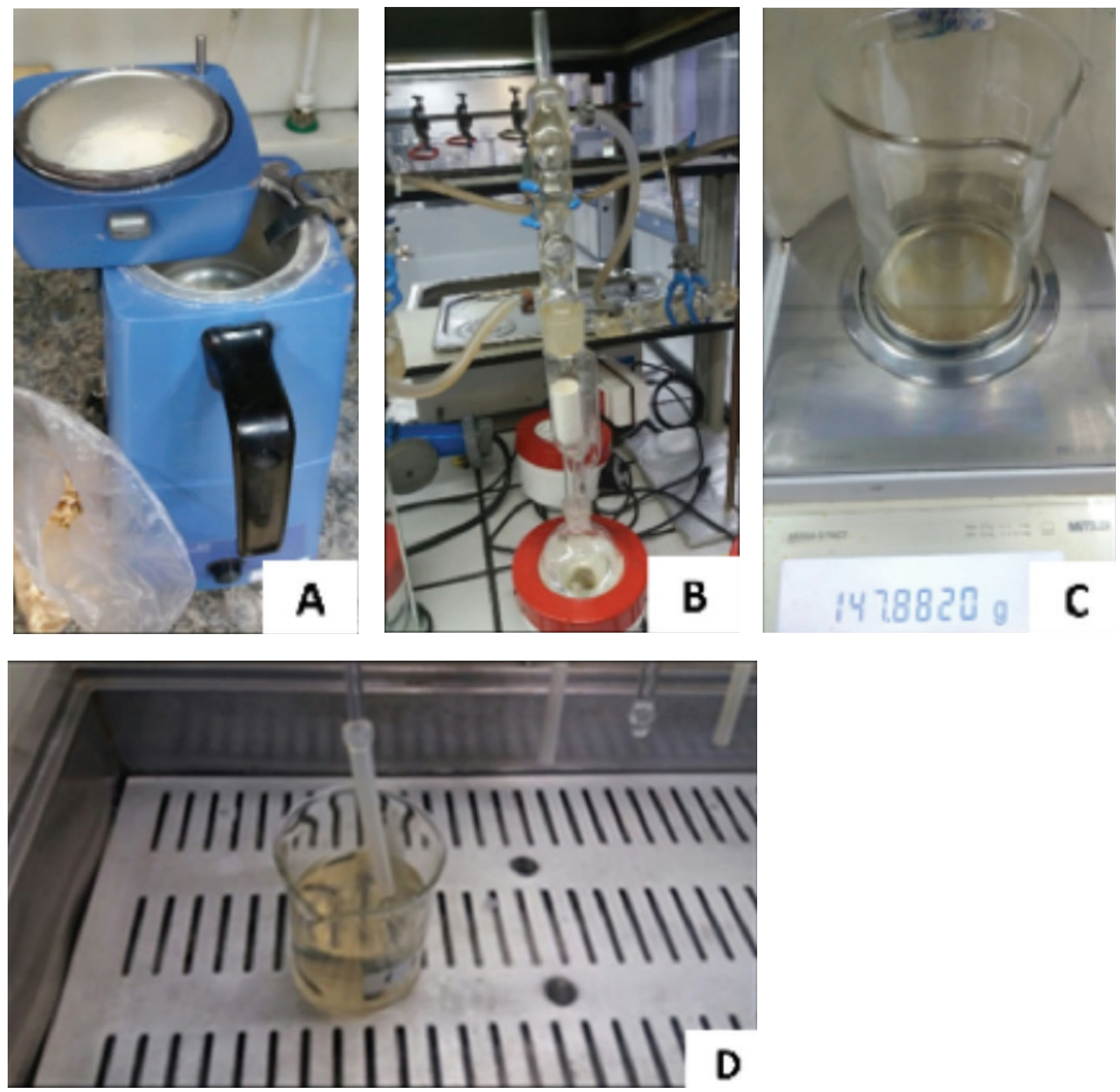

Figure 2 - Phytotherapeutic extraction process (Soxhlet), a) industrial mil b) Soxhlet Extrator c) water bath with $\mathrm{O}_{2}$ d) Extraction transferred to Becker. 


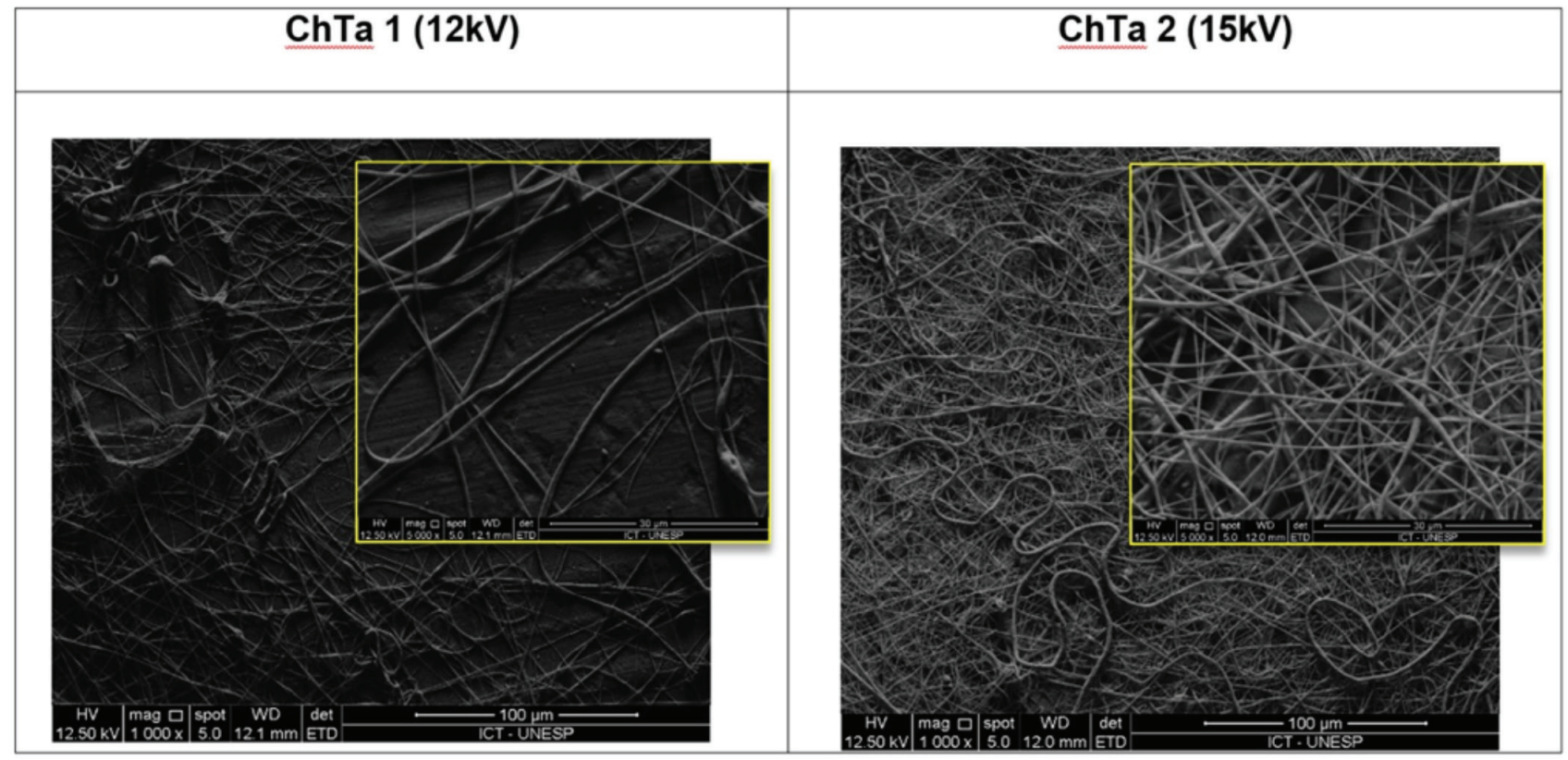

Figure 3 - Micrographs obtained by SEM - Lower yield.

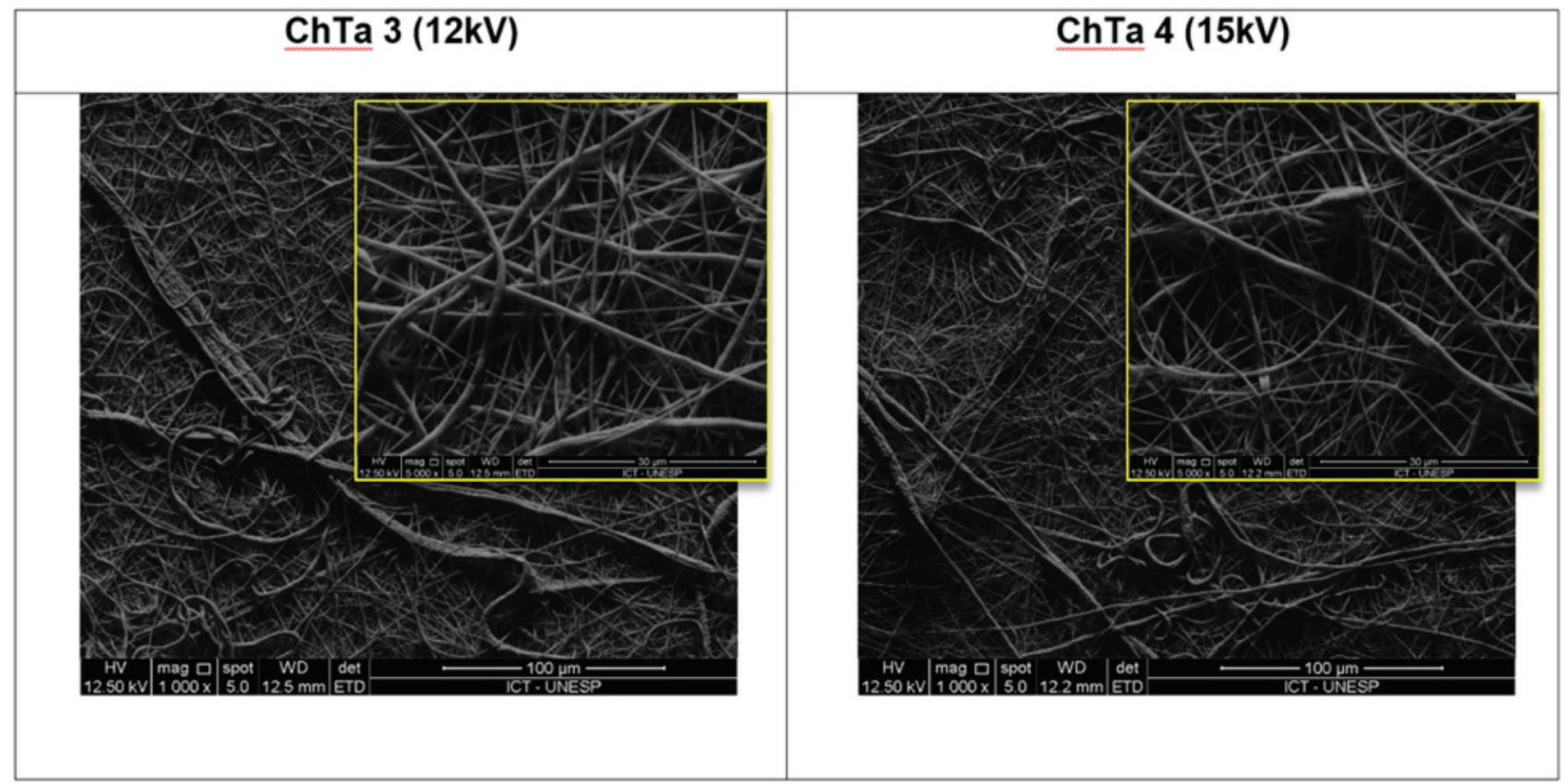

Figure 4 - Micrographs obtained by SEM - Higher yield. 


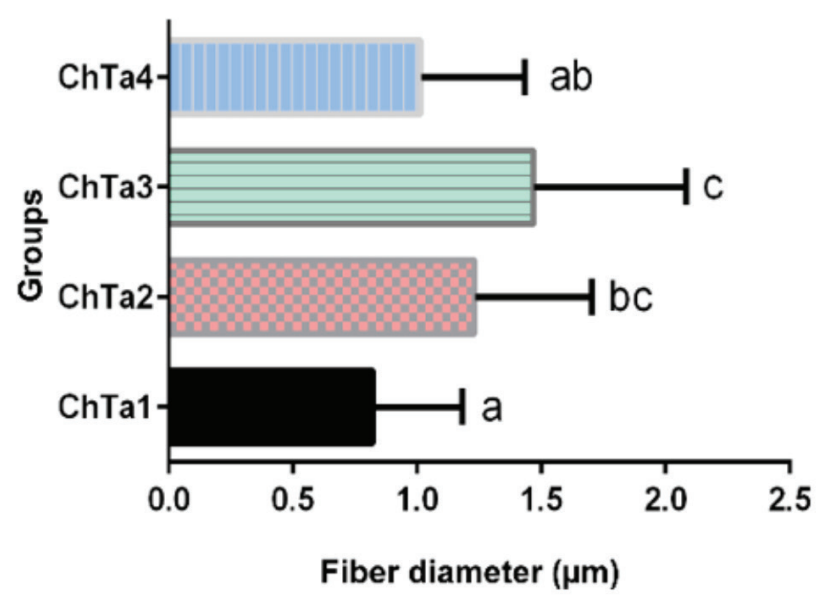

Figure 5 - Statistical analysis Anova 1-factor of diameter fiber measurement.

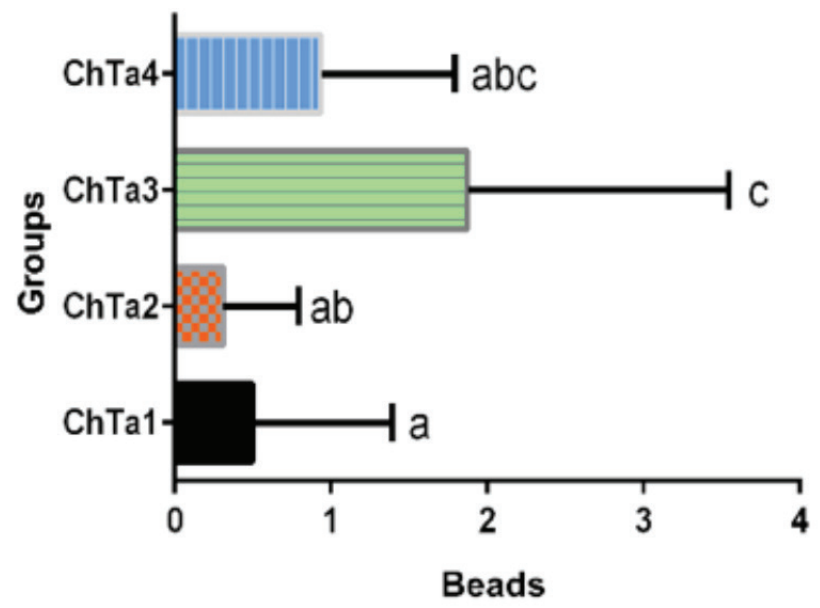

Figure 6 - Statistical analysis Anova 1-factor of the presence of beads in the fibers.

\section{DISCUSSION}

Tissue engineering is now expanding its application in the medical and dental areas mainly by means of biomaterials, synthetic or natural, that can be used for a period of time, completely or partially as part of a system that treats, increases or replaces any tissue, organ or function of the body [9].

The use of herbal medicine with a polymer is a common studied composition of biomaterials, since PCL is widely used in the biomedical field due to its mechanical resistance and slow degradability [23] and Tannins present antimicrobial and antiinflammatory properties [26].
Scaffolds of nanofibers can be used as efficient carriers of antibacterial and therapeutic agents that play an active role in the wound healing process [23]. These scaffolds impregnated with herbal medicine can be an interesting alternative to the conventional treatments, allowing drug delivery systems.

For this study, two methods were used to extraction of the Tara extract (Rota-vapor and Soxhlet extrator), but there was no influence of the methods in the fibers formation and characteristics, its represented only just different rates of synthesis yield were obtained.

In this study, it was verified that the formation of fibers happened only under specific combinations of the synthesis parameters (constant flow rate of $0.8 \mathrm{mLh}-1$ ) observed under 12 and $15 \mathrm{kV}$ and $12 \mathrm{~cm}$ distance of the metallic capillary to the, with significant beads formation.

The lower fiber diameter was presented by ChTa1, characterizing better compliance for biological systems, justified by several studies that observed higher growth, proliferation, cell spreading in materials of smaller caliber $[27,28]$. Meanwhile, the ChTa4 group had the highest mean diameter. Besides that, it is known that the solution concentration and viscosity can be also influencing factors for fiber diameter, but these variables were limited in this study [29].

As regards beads nanofibers, ChTa3 presented the highest formation of these structures, that can be considered defects from the mechanical approach [30]. or even drugs reservoirs from the biological approach.

\section{CONCLUSION}

It can be concluded that it is possible to obtain an effective synthesis of electrospun membranes of PCL and Caesalpinia spinosa extract, indicating a potential of therapeutic application for lesions such as prosthetic stomatitis.

\section{ACKNOWLEDGMENTS}

To the chemist Robenildo Pereira da Silva for his support and all the support along with the synthesis methodologies of the tare extracts. 


\section{REFERENCES}

1. Casaroto AR, Lara VS. Phytomedicines for Candida-associated denture stomatitis. Fitoterapia. 2010;81(5):323-8.

2. Mccullough MJ, Ross BC, Reade PC. Candida albicans: a review of its history, taxonomy, epidemiology, virulence attributes, and methods of strain differentiation. Int J Oral Maxillofac Surg.1996;25(2):136-44.

3. Coco BJ, Bagg J, Cross LJ, Jose A., Cross J, Ramage G. Mixed Candida albicans and Candida glabrata populations associated with the pathogenesis of denture stomatitis. Oral Microbiol Immunol. 2008;23(5):377-83.

4. Millns B, Martin, MV. Nystatin pastilles and suspension in the treatment of oral candidosis. Br Dent J. 1996;181(6):209.

5. Karakis D, Akay C, Oncul B, Rad AY, Dogan A. Effectiveness of disinfectants on the adherence of Candida albicans to denture base resins with different surface textures. J Oral Sci. 2016;58(3):431-7.

6. Kongstad KT, Özdemir C, Barzak A, Wubshet SG, Staerk D. Combined use of high-resolution $\alpha$-glucosidase inhibition profiling and high-performance liquid chromatography-high-resolution mass spectrometry-solid-phase extraction-nuclear magnetic resonance spectroscopy for investigation of antidiabetic principles in crude plant extracts. J Agric Food Chem. 2015;63(8):2257-63.

7. Donnelly RF, Mccarron PA, Tunney MM. Antifungal photodynamic therapy. Am J Microbiol Res. 2008;163(1):1-12.

8. Maver-biscanni M, Mravak-stipetic M, Jerolimov V. Effect of low-level laser therapy on Candida albicans growth in patients with denture stomatitis. Photomed Laser Surg. 2005; 23(3):328-32.

9. Bellotti N, Del Amo B, Romagnoli R. Caesalpinia spinosa tannin derivatives for antifouling formulations. Procedia Mater Sci. 2012:1(1):259-65.

10. Guevara JM, Guevara JC, Guevara JMD, Béjar V, Huanam A, Valencia E, et al. Evaluación del cocimiento de diferentes biovariedades de Caesalpinia spinosa (tara) frente a cepas de Staphylococcus aureus sensibles y resistentes a oxacilina. In: Anales de la Facultad de Medicina. UNMSM. Facultad de Medicina; 2014. p.177-80.

11. Lewis GP, Schrire BD. A reappraisal of the Caesalpinia group (Caesalpinioideae: Caesalpinieae) using phylogenetic analysis. Adv Leg Syst. 1995;7:41-52.

12. Galvez JG, Riedl B, Conner AH. Analytical studies on tara tannins. Holzforschung. 1997;51(3):235-43.

13. Valachová K, Topol'ská D, Nagy M, Gaidau C, Niculescu M, Matyašovský $J$ et al. Radical scavenging activity of Caesalpinia spinosa Neuro Endocrinol Lett. 2014;35(2):197-200.

14. Gali-muhtasib HU, Yamout SZ, Sidani MM. Tannins protect against skin tumor promotion induced by ultraviolet-B radiation in hairless mice. Nutr Cancer. 2000;37(1):73-7.
15. Urueña C, Mancipe J; Hernandez J: Castaneda D, Pombo L, Gomez $A$, et al. Gallotannin-rich Caesalpinia spinosa fraction decreases the primary tumor and factors associated with poor prognosis in a murine breast cancer model. BMC Complement Altern Med. 2013;13(1):74.

16. Sandoval TA, Urueña C, Llano M, Gómez-Cadena A, Hernández JF, Sequeda $L G$, et al. Standardized extract from Caesalpinia spinosa is cytotoxic over cancer stem cells and enhance anticancer activity of doxorubicin. Am J Chin Med. 2016;44(08):1693-1717.

17. Yarin AL. Coaxial electrospinning and emulsion electrospinning of core-shell fibers. Polym Adv Technol. 2011;22(3):310-7.

18. Doshi J, Reneker, DH. Electrospinning process and applications of electrospun fibers. J Electrostat.1995; 35(2-3):151-60.

19. Wei $Q$, Tao D, Xu Y. Nanofibers: principles and manufacture. In: Wei $Q$ (ed). Functional Nanofibers and their Applications. 2012. p.3-21.

20. Venugopal J, Ramakrishna, S. Applications of polymer nanofibers in biomedicine and biotechnology. Appl Biochem Biotechnol. 2005;125(3):147-57.

21. Kim HS, Yoo HS. Therapeutic application of electrospun nanofibrous meshes. Nanomed.2014:9(4):517-33.

22. Monteiro AP, Rocha CM, Oliveira MF, Gontijo SM, Agudelo RR, Sinisterra $\mathrm{RD}$, et al. Nanofibers containing tetracycline/ $\beta$-cyclodextrin: physicochemical characterization and antimicrobial evaluation. Carbohydrate Polymers. 2017;156:417-26.

23. Figueira DR, Miguel SP, de Sá KD, Correia IJ. Production and characterization of polycaprolactone-hyaluronic acid/chitosan-zein electrospun bilayer nanofibrous membrane for tissue regeneration. International journal of biological macromolecules. 2016; 93:1100-10.

24. Gassner F, Owen, AJ. Physical properties of poly ( $\beta$-hydroxybutyrate)poly ( $\varepsilon$-caprolactone) blends. Polymer. 1994;35(10):2233-6.

25. Souza MA, Oliveira JE, Medeiros JS, Glenn GM, Mattoso, LH. Controlled release of linalool using nanofibrous membranes of poly (lactic acid) obtained by electrospinning and solution blow spinning: a comparative study. J Nanosci Nanotechnol. 2015;15(8):5628-36.

26. Liao SG, Zhang LJ, Sun F, Zhang JJ, Chen AY, Lan YY, et al. Antibacterial and anti-inflammatory effects of extracts and fractions from Polygonum capitatum. J Ethnopharmacol. 2011;134(3):1006-9.

27. Christopherson GT, SONG H, Mao H. The influence of fiber diameter of electrospun substrates on neural stem cell differentiation and proliferation. Biomaterials. 2009;30(4): 556-64.

28. Venugopal J, Low S, Choon AT, Ramakrishima S. Interaction of cells and nanofiber scaffolds in tissue engineering. J Biomed Mater Res B. 2008;84(1):34-48.

29. Li Z, Wang C. One-Dimensional nanostructures: Electrospinning Technique and Unique Nanofibers: Springer Berlin Heidelberg; 2013.

30. Huang ZM, Zhang Y,Ramakrishna S, Lim CT. Electrospinning and mechanical characterization of gelatin nanofibers. Polymer. 2004:45(15):5361-8.

Tabata Prado Sato

(Corresponding address)

Instituto de Ciência e Tecnologia - UNESP

Depto de materiais Dentários e Protese

Av. Dr. Eng.Francisco Jose Longo, 777, Jd. Sao Dimas

Sao Jose dos Campos, Brazil

Email: tabata.sato@ict.unesp.br

Date submitted: 2018 Nov 07

Accept submission: 2019 Jan 21 